\title{
Citrus: Safe Handling Practices for Consumers ${ }^{1}$
}

\author{
Amy Simonne and Mark Ritenour ${ }^{2}$
}

Fresh citrus is rich in many nutrients and has not been traced to any cases of foodborne illness. However, fresh unpasteurized orange juice has been associated with several outbreaks of foodborne illnesses. This document describes steps you can take to reduce your risk of foodborne illness from fresh citrus and home made citrus juice.

\section{Where You Shop:}

- Buy citrus that is not visibly bruised or damaged (cuts, scrapes, etc). Examine the stem end for areas where the peel may have been torn during harvest. Any wounds provide hiding places for microbial contamination.

- Be sure freshly squeezed citrus juice is covered and kept cold.

- Those who are more susceptible to sicknesses (depressed natural immunity) should consume only pasturized citrus juice and not unpasteurized juice.

\section{At Home:}

- Refrigerate fresh citrus products within two hours of peeling or cutting.
Leftover cut citrus and freshly squeezed juice should be discarded after two hours at room temperature.

\section{During Preparation:}

- Wash hands with hot soapy water before and after:

- handling raw meat, poultry, or seafood

- using the bathroom

- changing diapers

- handling pets

- handling fresh produce

- Wash citrus with cool tap water just before preparing or eating even if the rinds will be removed. Don't use soap or detergents (they

1. This publication is FCS8739, one of a series of the Department of Family, Youth and Community Sciences, Florida Cooperative Extension Service, IFAS, University of Florida. Publication: November 2002. Please visit the EDIS Web site at http://edis.ifas.ufl.edu

2. Amy Simonne, Ph.D., assistant professor, Department of Family, Youth and Community Sciences; and Mark Ritenour, Ph.D., assistant professor, Horticultural Sciences Department, Cooperative Extension Service, IFAS, University of Florida, Gainesville, 32611. Reviewed by Linda B. Bobroff, Ph.D. RD, LD/N, associate professor, Department of Family, Youth and Community Sciences, Elizabeth M. Lamb, PhD., assistant professor, Horticultural Sciences Department, Cooperative Extension Service, IFAS, University of Florida, Gainesville, 32611.

The Institute of Food and Agricultural Sciences is an equal opportunity/affirmative action employer authorized to provide research, educational information and other services only to individuals and institutions that function without regard to race, color, sex, age, handicap, or national origin. For information on obtaining other extension publications, contact your county Cooperative Extension Service office. Florida Cooperative Extension Service / Institute of Food and Agricultural Sciences / University of Florida / Christine Taylor Waddill, Dean 
may contain materials not approved for food contact).

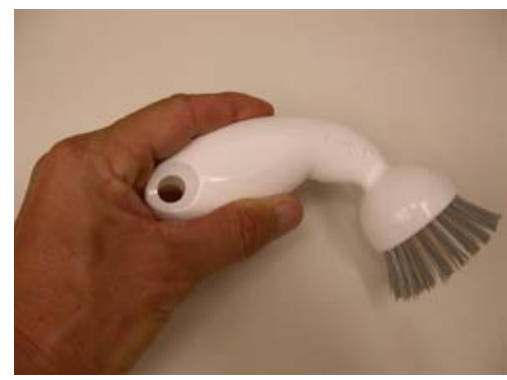

- Scrub citrus fruits with a clean produce brush before making juice or putting slices into tea or other drinks. Rinse fruit well with cool tap water.

- Examine fruit and cut away areas with minor wounds (cuts, scrapes, or ripped peel) where microorganisms can hide. Discard fruit with visible decay.

- Avoid eating the citrus peel, except on fruits such as kumquats that are eaten whole. It's okay to use citrus peel in baking (the heat kills pathogens).

- Wash cutting boards, dishes, utensils, and counter tops often. This prevents cross contamination of clean produce by a dirty surface or utensil. Use hot soapy water and rinse well. Wash and then sanitize these items after contact with fresh produce, or raw meat, poultry, or seafood (see box).

- Wash and sanitize kitchen sink frequently to prevent a build up of microbes.

- If possible, use separate cutting boards for fresh produce and raw meat (beef, poultry, or seafood).

- Do not consume ice that has come in contact with raw meat, fresh produce, or other raw products.
- Use a cooler with ice or ice gel packs when perishable foods are taken outdoors. This includes cut fresh fruits and vegetables.

To sanitize cutting boards, dishes, utensils:

- Mix one teaspoon chlorine bleach in one quart water

- Pour the mixture onto surface and let sit at least one minute

- Rinse well with hot running water

Counter tops can be sanitized by using the above solution mix, sanitizing sprays or wipes as an additional safety measure.

Following these steps will help reduce your risk of foodborne illness from fresh citrus.

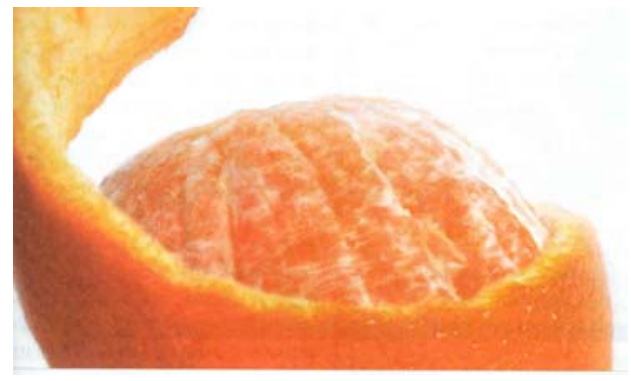

\section{For more information}

visit the Food and Drug Administration (FDA)

website at: http://www.fda.gov or call FDA Consumer Inquiries at 1-888-SAFEFOOD (a toll-free number). 